\title{
FLUKTUASI HARGA CABAI MERAH KERITING (Capsicum annum L) DI SENTRA PRODUKSI DAN PASAR INDUK \\ (Tinjauan Harga Cabai Merah Keriting di Kecamatan Cikajang dan Pasar Induk Kramat Jati Jakarta) ${ }^{1}$
}

\author{
Oleh: \\ DETY SUKMAWATI, LIES SULISTYOWATI, \\ MAMAN H. KARMANA, E KUSNADI WIKARTA \\ Universitas Winaya Mukti, Universitas Padjadjaran \\ e-mail: detysukmawati@ymail.com
}

\begin{abstract}
Abstrak
Cabai merah merupakan salah satu komoditas yang memiliki fluktuasi harga yang cukup besar. Fluktuasi harga cabai merah dapat disebabkan oleh besarnya jumlah penawaran dan besarnya jumlah permintaan. Semakin tinggi jumlah penawaran maka harga akan rendah, sedangkan semakin sedikitnya jumlah penawaran harga akan semakin meningkat (ceteris paribus). Harga cabai merah yang sangat fluktuatif menjadikan komoditas ini sulit untuk dapat diprediksi (Murhalis , 2007) . Berdasar sifat dan masalahnya rancangan penelitian ini termasuk deskriptip yaitu untuk mengetahui tinjauan harga caba merah keriting dan disertai statistik deskriptif untuk mengetahui fluktuasi/stabilitas harga cabai merah keriting di sentra produksi dan pasar induk. Penelitian ini menggunakan data time series harga cabai merah pada sentra produksi cabai merah keriting Cikajang Kabupaten Garut dan Pasar Induk Kramat Jati, dengan menggunakan data harga cabai merah keriting harian pada tahun 2014 . Data yang digunakan bersumber dari Dinas Pertanian Tanaman Pangan Jawa Barat dan dianalisis dengan menggunakan program EVIEWS 8. Fluktuasi harga cabai merah kertiitng di ke 2 tempat mengalami fluktuasi harga yang tinggi dari jenis sayuran lainnya. Cabai merah merupakan komoditas yang mengalami fluktuasi harga setiap waktu. Dalam kurun waktu 10 tahun perkembangan harga cabai merah di 2 tempat mengalami fluktuasi dengan rentang yang berbeda. Harga di pasar induk lebih berfluktuasi dari sentra produksi . Hal ini berdasar hasil analisis standar deviasi sentra produksi Cikajang $(15165,64)$ dan Pasar Induk Kramat Jati $(18302,01)$. Ketidakstabilan harga tersebut dikarenakan di pasar mekanisme pasar tidak bekerja, distribusi antar pelaku pasar tidak adil hal ini menunjukkan bahwa pasar cabai merah tidak efisien atau tidak sehat. Pasar tidak sehat ditunjukkan dengan harga terlalu murah akan merugikan produsen, dan harga terlalu mahal merugikan konsumen, hal ini terjadi akibat perubahan penawaran dan permintaan yang menimbulkan fluktuasi harga sehingga fluktuasi harga secara ekonomi akan menyulitkan prediksi bisnis.
\end{abstract}

Kata kunci: fluktuasi harga, sentra produksi, pasar induk

\section{PENDAHULUAN}

Komoditas cabai merah di provinsi Jawa Barat secara nasional merupakan salah satu komoditas unggulan. Pada tahun 2007 produktivitas cabai di garut diatas rata-rata produktivitas di Jawa Barat (Adang agustian dan Iwan Setiajie A, 2008). Luas tanam per Tahun cabai merah di Sentra produksi sayuran kabupaten Garut ( 3.038 ha) merupakan luas tanam terluas dari sentra produksi sayuran cabai merah di Jawa Barat yaitu Bandung, Cianjur, Majalengka dan Tasikmalaya (Dinas Pertanian Tanaman Pangan Provinsi Jawa Barat, 2013).

1 Makalah telah dipresentasikan pada Seminar Internasional ICBESS 2014 di Kuta Bali,25-26 Agustus 2014
Seperti halnya komoditas hortikultura pada umumnya, peranan pemasaran pada komoditas cabai merah memberikan kontribusi penting dalam peningkatan kinerja usahatani komoditas cabai merah secara keseluruhan mengingat sifat unik komoditas hortikultura secara umum seperti mudah busuk, mudah rusak, volumenious, produksinya bersifat musiman sementara konsumsi terjadi sepanjang tahun. Secara empiris dilapangan seringkali dijumpai bahwa para petani produsen tampaknya tetap saja menghadapi fluktuasi harga terutama saat panen, dan para pedaganglah yang dapat lebih akses untuk dapat memperoleh harga yang lebih tinggi, oleh karena itu, peningkatan produksi komoditas pertanian termasuk cabai merah perlu diiringi dengan perbaikan pada sistem pemasarannya, sehingga pihak petani sebagai 


\section{MIMBAR \\ Agribisnis}

ISSN 2460-4321

Volume 1 • Nomor 2 • Januari 2016

produsen komoditas ini diharapkan dapat memperoleh bagian harga yang memadai bagi peningkatan usahataninnya ( Agustian dan Setiajie A, 2008).

Cabai merah merupakan salah satu komoditas yang memiliki fluktuasi harga yang cukup besar. Fluktuasi harga cabai merah dapat disebabkan oleh besarnya jumlah penawaran dan besarnya jumlah permintaan. Semakin tinggi jumlah penawaran maka harga akan rendah, sedangkan semakin sedikitnya jumlah penawaran harga akan semakin meningkat (ceteris paribus). Harga cabai merah yang sangat fluktuatif menjadikan komoditas ini sulit untuk dapat diprediksi ( Murhalis , 2007)

Tinjauan Harga cabe di pasar domestik pada bulan Januari 2012 turun sebesar 4,83\% dibandingkan bulan Desember 2011. Harga cabe di pasar domestik pada bulan Januari 2012 turun sebesar $31,70 \%$ dibandingkan bulan Januari 2011. Harga cabe secara nasional cenderung berfluktuasi dengan koefisien keragaman harga bulan Januari 2011 sampai dengan bulan Januari 2012 sebesar 33,19\%. Disparitas harga cabe antar wilayah pada bulan Januari 2011 sampai dengan bulan Januari 2012 cukup tinggi dengan koefisien keragaman harga antar wilayah sebesar $42,46 \%$. Harga rata-rata cabe di 33 kota pada Januari 2012 turun sebesar 4,83\% jika dibandingkan dengan Desember 2011 yakni dari harga sebesar Rp.28.968, $-/ \mathrm{kg}$ menjadi Rp.27.569,-/kg. Sedangkan jika dibandingkan dengan Januari 2011, terjadi penurunan harga sebesar $31,70 \%$. Cabe merupakan salah satu komoditas yang memiliki fluktuasi harga besar. Fluktuasi harga cabe dapat disebabkan oleh besarnya jumlah penawaran dan besarnya jumlah permintaan. Semakin tinggi jumlah penawaran maka harga akan rendah, sedangkan semakin sedikitnya jumlah penawaran harga akan semakin meningkat. Pada bulan Januari 2012 harga cabe mulai mengalami penurunan harga secara nasional, karena beberapa wilayah dapat memenuhi pasokannya dari wilayah lain.

\section{TINJAUAN PUSTAKA}

Rangsangan ekonomi dalam bentuk tingkat harga yang menguntungkan, merupakan faktor paling penting bagi petani untuk meningkatkan produksinya, seperti juga berlaku bagi setiap bagi setiap produsen di sektor-sektor lain.
Petani pada akhirnya akan merasa tidak ada untungnya memperluas lahan garapan, menerapkan teknologi baru, memakai pupuk berkualitas baik tetapi dengan harga lebih mahal daripada pupuk organik, dan melakukan diversifikasi produksi apabila semua itu tidak menambah penghasilan netonya. Dalam kata lain, harga merupakan faktor utama, sementara intensifikasi dan ekstensifikasi, dan sebagainya hanyalah merupakan faktor-faktor penunjang untuk meningkatkan produksi. Pada akhirnya petani sendiri yang menentukan untuk menambah produksi atau tidak, karena dia yang melakukan produksi, bukan pemerintah atau pihak lain.

Karena harga merupakan faktor utama, oleh karena itu agar kebijakan menaikkan output pertanian lewat pemberian insentif harga bisa berhasil, pemerintah harus mengetahui betul bagaimana respons penawaran / suplai di sektor pertanian terhadap perubahan harga. Respons akan berbeda menurut jenis komoditi bahkan antar petani di dalam katagori tanaman yang sama, tergantung pada tujuan petani melakukan kegiatan bertani dan kondisi ekonominya. Besarnya respons penawaran juga sangat informatif bagi pembuat -pembuat kebijakan dalam mengevaluasi kebijakan yang dibuat dalam bidang pertanian.

Teori dasar dari respons penawaran pertanian adalah bahwa faktor-faktor insentif, termasuk harga berpengaruh positif terhadap output atau penawaran pertanian. Respons penawaran pertanian dapat dianalisis dari titik output agregat atau suplai, output subsektor (yakni output tanaman ) atau tanaman secara individu (misalnya padi, jagung, teh dan sebagainya). Tingkat agregat yang dipilih tergantung daripada tujuan dari studi yang akan dilakukan dan tentu tergantung pada ketersedian data. Output atau suplai pertanian dapat dilihat dalam salah satu dari berikut ini : (a) Luas lahan yang digarap; (b) Output per ha; dan (c) Hasil panen (Mamingi,1996 dalam Tambunan, 2003)

Petani sebagai penerima harga, maka untuk mendapatkan harga yang lebih menguntungkan petani harus mampu memanfaatkan variasi harga yang terjadi di pasar baik menurut tempat, bentuk produk, waktu maupun kualitas produk. Hal ini berarti bahwa petani harus mampu mengatur pola penawarannya dengan 


\section{Fluktuasi Harga Cabai Merah Keriting (Capsicum annum L) di Sentra Produksi dan Pasar Induk (Tinjauan Harga Cabai Merah Keriting di Kecamatan Cikajang dan Pasar Induk Kramat Jati Jakarta) \\ DETY SUKMAWATI, LIES SULISTYOWATI, MAMAN H. KARMANA, E KUSNADI WIKARTA}

mengatur kegiatan produksinya dan mengatur kegiatan pemasarannya yang disesuaikan dengan kebutuhan pasar. Namun demikian akibat berbagai faktor petani seringkali tidak mampu mengatur pola penawarannya pada pasar yang lebih menguntungkan. Ketidakmampuan petani tersebut antara lain dipengaruhi oleh penguasaan lahan garapan yang sempit, keterbatasan sumber pendapatan non pertanian, keterbatasan fasilitas kredit, dan keterbatasan sarana transportasi di daerah pedesaan (Rao dan Subbrao, 1987, Utami dan Ihalow, 1993 dalam Irawan,2007).

\section{METODE PENELITIAN}

Berdasar sifat dan masalahnya rancangan penelitian ini termasuk deskriptip yaitu untuk mengetahui tinjauan harga caba merah keriting dan disertai statistik deskriptif untuk mengetahui fluktuasi/stabilitas harga cabai merah keriting di sentra produksi dan pasar induk . Penelitian ini menggunakan data time series harga cabai merah pada sentra produksi cabai merah keriting Cikajang Kabupaten Garut dan Pasar Induk Kramat Jati, dengan menggunakan data harga cabai merah keriting harian pada tahun 2014. Data yang digunakan bersumber dari Dinas Pertanian Tanaman Pangan Jawa Barat dan dianalisis dengan menggunakan program EVIEWS 8.

\section{HASIL DAN PEMBAHASAN}

Kecamatan Cikajang Kabupaten Garut merupakan sentra produksi cabai merah dengan luas tanam terluas (3.921 ha) di Jawa Barat, dari sentra produksi cabai merah lainnya di Jawa Barat yaitu Bandung, cianjur dan majalengka. Cabe merah keriting dari sentra produksi Cikajang mengirim pada beberapa pasar tujuan pengiriman diantaranya pasar induk kramat jati dan pasar induk caringin kota Bandung, pada tahun 2012 jumlah pasokan rata-rata 28,49 ton (Dinas Pertanian Tanaman Pangan Jawa Barat, 2013 (data diolah)). Cabe merah keriting mampu memasok secara kontinyu karena pertanaman yang dilakukan tidak hanya monokultur tetapi bisa tumpangsari. Dalam kurun 10 tahun perkembangan harga di 4 tempat mengalami fluktuasi dengan rentang yang sangat berbeda, harga di sentra produksi lebih rendah dari ketiga Pasar Induk dan harga di Pasar Induk Gede Bage berbeda dengan
Pasar Induk Caringin, walaupun kedua tempat tersebut terdapat pada kota yang sama dan harga di pasar induk kramat jati melebihi pasar induk caringin hanya tahun 2005 harga di pasar induk gede bage dibawah harga sentra produksi cikajang hal ini bisa terjadi jumlah pasokan di pasar induk gede bage banyak artinya komoditas yang masuk pada pasar tersebut berasal dari lebih satu pemasok. Hal ini mengidikasikan bahwa harga tidak stabil selama 10 tahun di ketiga tempat, apakah harga tidak stabil, mekanisme pasar tidak bekerja, distribusi hasil antar pelaku pasar tidak adil, hal menunjukkan pasar tidak sehat.

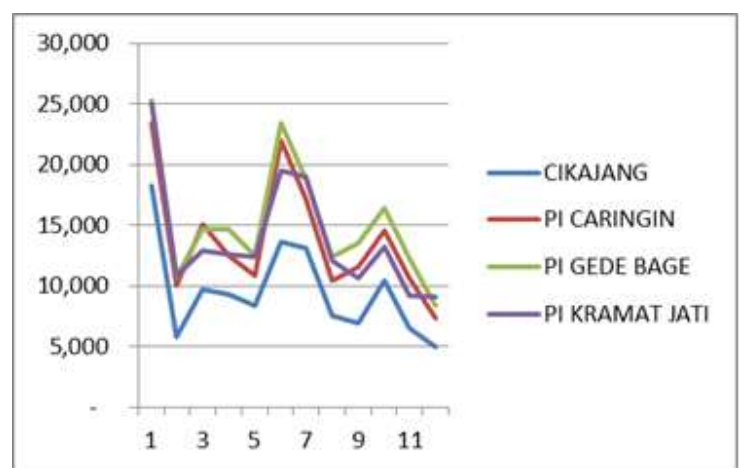

Sumber : Dinas Pertanian Tanaman Pangan Provinsi Jawa Barat 2013 (Diolah)

Gambar 1. Perkembangan Harga Cabai Merah Keriting di Cikajang, Pasar Induk Caringin, Pasar Induk Gede Bage dan Pasar Induk Kramat Jati per Bulan Tahun 2012

Harga produk pertanian tergolong sangat fluktuatif dengan rentang tingkat harga yang sangat lebar, apalagi setelah dikaitkan dengan future trading. Pada waktu tertentu, seperti musim panen dan musim hujan harganya bisa sangat rendah namun pada saat yang lain bisa sangat tinggi. Harga yang sangat fluktuatif secara teoritis akan menyulitkan prediksi bisnis, baik dalam perhitungan rugi laba maupun manajemen resiko. Harga yang demikian seringkali hanya menguntungkan para spekulan yang umumnya para pedagang tertentu yang mampu mengelola stok secara baik dan cermat. Pengendalian fluktuasi ini merupakan tantangan tersendiri khususnya dalam perumusan kebijakan yang tepat terutama menyangkut kebijakan proteksi pasar domestik dan perlindungan harga di tingkat petani (Ismet.2009). 


\section{AIMBAR \\ Agribisnis}

ISSN 2460-4321

Volume 1・Nomor 2・Januari 2016

Fluktuasi harga yang sangat tinggi merupakan salah satu isu sentral sering muncul dalam pemasaran komoditas hortikultura. Fluktuasi harga yang tinggi menyebabkan penerimaan dan keuntungan usaha yang diperoleh petani dari hasil kegiatan usahataninya sangat berfluktuasi. Kondisi demikian tidak kondusif bagi pengembangan agribisnis hortikultura karena keuntungan yang diperoleh dari kegiatan tersebut menjadi tidak stabil padahal tingkat keuntungan yang tinggi dan stabil umumnya merupakan daya tarik utama bagi pelaku bisnis untuk melakukan investasi dan memperluas usahanya.

Di banding komoditas padi dan palawija nilai koefisien variasi harga sayuran lebih besar, dengan kata lain harga sayuran lebih berfluktuasi dibanding harga padi dan palawija. Fluktuasi harga komoditas pada dasarnya terjadi akibat ketidakseimbangan antara kuantitas pasokan dan kuantitas permintaan yang dibutuhkan konsumen. Jika terjadi kelebihan pasokan maka harga komoditas akan turun, sebaliknya jika terjadi kekurangan pasokan maka harga akan naik. Dalam proses pembentukan harga tersebut perilaku petani dan pedagang memiliki peranan penting karena mereka dapat mengatur volume penjualannya yang disesuaikan dengan kebutuhan konsumen. Berdasarkan hal tersebut maka dapat dikatakan bahwa fluktuasi harga yang relatif tinggi pada komoditas sayuran pada dasarnya terjadi akibat kegagalan petani dan pedagang sayuran dalam mengatur volume pasokannya sesuai dengan kebutuhan konsumen ( Irawan, 2007).

Seperti halnya komoditas hortikultura pada umumnya, peranan pemasaran pada komoditas cabai merah memberikan kontribusi penting dalam peningkatan kinerja usahatani komoditas cabai merah secara keseluruhan mengingat sifat unik komoditas hortikultura secara umum seperti mudah busuk, mudah rusak, volumenious, produksinya bersifat musiman sementara konsumsi terjadi sepanjang tahun. Sementara itu, disisi lain para konsumen menghendaki komoditas tersedia dekat dengan tempat mereka, dapat diperoleh sepanjang waktu dan dapat dikonsumsi dalam bentuk segar. Dua keinginan yang berbeda ini akan dapat dipenuhi dengan adanya suatu sistem pemasaran yang baik (Adang Agustian dan Iwan Setiajie A, 2008). Pada gambar dibawah ini terlihat fluktuasi harga sayuran di sentra produksi dan beberapa Pasar Induk. Dari hal tersebut terlihat fluktuasi harga cabai keriting mengalami fluktuasi yang tinggi dari komoditas sayuran lainnya.

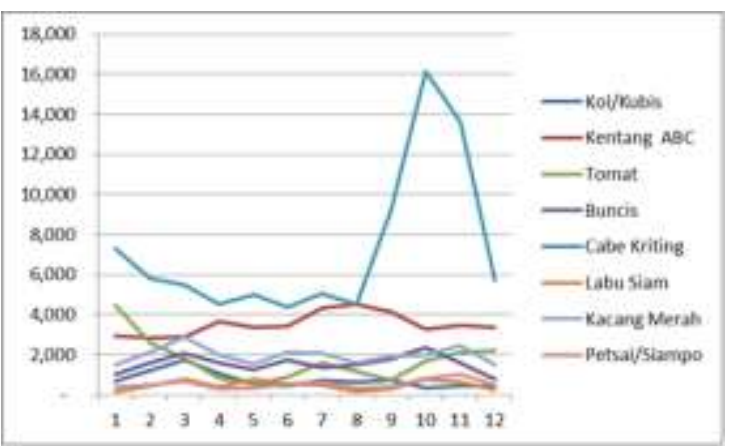

Sumber : Dinas Pertanian Tanaman Pangan Provinsi Jawa Barat.( Diolah)

\section{Gambar 2. Harga Sayuran di Sentra Produksi} Cikajang, Kabupaten Garut

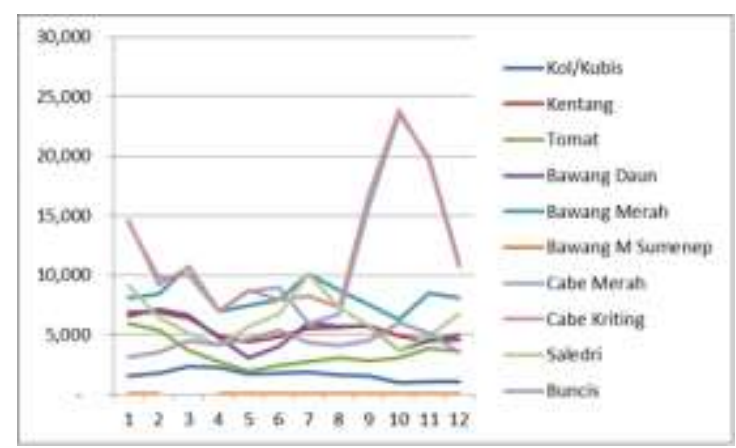

Sumber : Dinas Pertanian Tanaman Pangan Provinsi Jawa Barat.( Diolah)

\section{Gambar 3. Harga Sayuran di Pasar Induk Kramat Jati Jakarta}

Hortikultura merupakan salah satu sektor pertanian yang berkembang pesat dalam pertanian Indonesia. Jenis tanaman yang dibudidayakan dalam hortikultur meliputi buahbuahan, sayur-sayuran, bunga dan tanaman hias. Sedangkan dalam hortikultur, sayuran adalah salah satu sumber vitamin dan mineral. Cabai merah (Capsicum annum) merupakan komoditas sayuran yang memiliki peranan penting bagi pertanian di Indonesia. Cabai merah biasa digunakan dalam bentuk segar maupun olahan. Cabai dalam bentuk segar dapat digunakan sebagai bumbu masakan, sambal dan penghias makanan. Sedangkan bentuk olahannya seperti saus sambal dan bubuk cabai. Cabai merah diminati pasar karena 


\section{Fluktuasi Harga Cabai Merah Keriting (Capsicum annum L) di Sentra Produksi dan Pasar Induk (Tinjauan Harga Cabai Merah Keriting di Kecamatan Cikajang dan Pasar Induk Kramat Jati Jakarta) \\ DETY SUKMAWATI, LIES SULISTYOWATI, MAMAN H. KARMANA, E KUSNADI WIKARTA}

rasa pedasnya yang khas. Penawaran komoditas cabai merah ini, masih sangat tergantung dari jumlah cabai yang diproduksi. Sedangkan jumlah produksi cabai yang dihasilkan sangat ditentukan oleh luas panen dan produktivitas lahan.

Cabai merah merupakan salah satu komoditas hortikultura unggulan nasional dan memiliki ekonomi yang cukup tinggi. Permintaan cabai merah setiap tahun cenderung meningkat seiring dengan pertambahan jumlah penduduk dan kegunaannya sebagai bahan konsumsi serta kebutuhannya sebagai bahan baku industri. Seperti halnya sifat produk pertanian , cabai merah merupakan komoditas yang mudah rusak (perishable), volumunius dan produksi bersifat musiman sementara konsumsi terjadi sepanjang tahun. Hal ini menimbulkan fluktuasi harga yang tinggi. Fluktuasi harga pada dasarnya akibat ketidakseimbangan antara jumlah permintaan dan penawaran yang terjadi di pasar, dimana harga meningkat jika jumlah permintaan melebihi penawaran dan sebaliknya harga menurun jika jumlah penawaran melebihi permintaan.

Dari ke 2 grafik tersebut terlihat bahwa :

1. Fluktuasi harga cabai merah kertiitng di ke 2 tempat mengalami fluktuasi harga yang tinggi dari jenis sayuran lainnya.

2. Fluktuasi harga cabai merah keriting seiring dengan fluktuasi harga cabai merah, dalam Berita Resmi statistik 2013 yang dikatagorikan cabai besar terdiri dari cabai merah besar, cabai merah keriting, dan cabai hijau besar, hal ini digunakan pada data perkembangan produksi secara nasional, tetapi dalam penggunaan di pasar terlihat bahwa harga cabai keriting berfluktuasi seiring dengan harga cabai merah, dalam penggunaannya di konsumen kedua jenis cabai ini saling melengkapi dan terkadang mengsubstitusi.

3. Cabai merah merupakan komoditas yang mengalami fluktuasi harga setiap waktu. Dalam kurun waktu 10 tahun perkembangan harga cabai merah di 2 tempat mengalami fluktuasi dengan rentang yang berbeda.

4. Harga di pasar induk lebih berfluktuasi dari sentra produksi . Hal ini berdasar hasil analisis standar deviasi sentra produksi
Cikajang $(15165,64)$ dan Pasar Induk Kramat Jati $(18302,01)$.

Ketidakstabilan harga tersebut dikarenakan di pasar mekanisme pasar tidak bekerja, distribusi antar pelaku pasar tidak adil hal ini menunjukkan bahwa pasar cabai merah tidak efisien atau tidak sehat. Pasar tidak sehat ditunjukkan dengan harga terlalu murah akan merugikan produsen, dan harga terlalu mahal merugikan konsumen, hal ini terjadi akibat perubahan penawaran dan permintaan yang menimbulkan fluktuasi harga sehingga fluktuasi harga secara ekonomi akan menyulitkan prediksi bisnis.

Menurut Irawan, 2007, fluktuasi harga komoditas pada dasarnya terjadi akibat ketidakseimbangan antara kuantitas pasokan dan kuantitas permintaan yang dibutuhkan konsumen. Jika terjadi kelebihan pasokan maka harga komoditas akan turun, sebaliknya jika terjadi kekurangan pasokan. Dalam proses pembentukan harga tersebut perilaku petani dan pedagang memiliki peranan penting karena mereka dapat mengatur volume penjualannya yang disesuaikan dengan kebutuhankonsumen. Berdasarkan hal tersebut maka dapat dikatakan bahwa fluktuasi harga yang relatif tinggi pada komoditas sayuran pada dasarnya terjadi akibat kegagalan petani dan pedagang sayuran dalam mengatur volume pasokannya sesuai dengan kebutuhan konsumen.

Petani sebagai penerima harga maka untuk mendapatkan harga yang lebih menguntungkan petani harus mampu memanfaatkan variasi harga yang terjadi di pasar baik menurut tempat, bentuk produk, waktu maupun kualitas produk. Hal ini berarti bahwa petani harus mampu mengatur pola penawarannya dengan mengatur kegiatan produksinya dan mengatur kegiatan pemasarannya (penyimpanan, sortasi dan grading, outlet pemasaran, dan sebagainya) yang disesuaikan dengan kebutuhan pasar. Namun demikian akibat berbagai faktor petani seringkali tidak mampu mengatur pola penawarannya pada pasar yang lebih menguntungkan. Ketidak mampuan petani tersebut antara lain dipengaruhi oleh penguasaan lahan garapan yang sempit, keterbatasan sumber pendapatan nonpertanian, keterbatasan fasilitas kredit, dan keterbatasan sarana transportasi di daerah perdesaan. 


\section{AIMBAR \\ Agribisnis}

ISSN 2460-4321

Volume 1・ Nomor 2・ Januari 2016

Fluktuasi harga tidak menguntungkan bagi pengembangan tanaman hortikultura. Fluktuasi harga seringkali lebih merugikan petani daripada pedagang, karena pada umumnya petani tidak dapat mengatur waktu penjualannya untuk mendapatkan harga jual yang menguntungkan. Fluktuasi harga yang tinggi juga memberi peluang bagi pedagang untuk memanipulasi informasi harga di tingkat petani sehingga tranamisi harga kepada petani cenderung asimetris dalam pengertian kenaikan harga di tingkat konsumen tidak diteruskan kepada petani secara cepat dan sempurna.

Kondisi klasik yang selalu terjadi pada sektor pertanian sayuran, merupakan terdapatnya dua sisi kepentingan yang berbeda antara keinginan petani dan konsumen. Petani menginginkan produksi yang tinggi dengan harga jual yang menguntungkan. Konsumen menginginkan harga komoditas tetap dinilai normal. Harga normal terjadi dengan harga keseimbangan artinya penawaran sama dengan permintaan, harga tinggi di pasar seringkali dinilai bahwa penawaran yang berkurang bagi pemerintah untuk kembali ke harga keseimbangan adalah dengan impor komoditas, bagi petani ,impor tersebut merupakan satu kebijakan yang merugikan.

Gejolak harga aneka komoditas sayuran karena pengaruh seringnya ketidakseimbangan pasokan dengan permintaan pasar. Upaya mengatasi ketidakseimbangan sebenarnya sudah lama dilakukan di jawa barat, dengan upaya budidaya sayuran secara greenhouse, dengan cara ini diharapkan diperoleh kontinuitas pasokan tanpa terpengaruh iklim dan lebih terkontrol dari risiko serangan hama penyakit. Pengenalan dan penggunaan greenhouse di Jawa Barat sudah sejak 1990, cara ini diminati petani di kecamatan Cikajang Kabupaten Garut dan Kecamatan Lembang Kabupaten Bandung, dengan teknik yang lebih murah., kemudian penggunaan green house untuk sayuran kurang berkembang, terutama pada saat krisis moneter 1999. Banyak petani beralih kembali ke usahatani tradisional karena biaya produksi yang tinggi. Kendala bertani sayuran melalui green house dihadapkan kepada modal besar untuk investasi awal, dan jika dihadapkan kepada situasi harga komoditas yang cepat berubah.
Salah satu usaha untuk menangulangi fluktuasi harga, Direktorat Jenderal hortikultura Kementrian Pertanian mengembangkan kawasan konsorsium PACAMAT (Paprika, cabe, tomat) di jawa barat. Salah satu kawasan tersebut adalah berada di daerah kabupaten Bandung Barat, Bandung, Sumedang, Garut, Tasikmalaya dan Ciamis. Beragam program dan bantuan modal diberikan ke wilayah tersebut, diantaranya program Lembaga Mandiri yang mengakar di masyarakat (LM3) Agribisnis Hortikultura, PMD (Penggerak Membangun Desa), Sekolah Lapang Good Agriculture Practise (SL-GAP) dan Sekolah Lapang Pengendalian Hama Terpadu (SL-PHT) dan dukungan fasilitas melalui pendanaan APBD. Integrasi pembangunan kawasan dan konsorsium Pacamat ini diharapkan bisa menghindari gejolak harga cabai dengan menggerakkan usaha cabai termasuk di lingkungan pekarangan rumah, namun penanaman cabai di pekarangan hanya bersifat penyangga atau buffer, fungsinya untuk ketahanan dalam rumah tangga, terutama keluarga yang pendapatannya berada di tingkat rata-rata. Kepala Dinas Tanaman Pangan Provinsi Jawa Barat menyatakan setiap orang rata-rata mengkonsumsi $3 \mathrm{~kg}$ cabai/ tahun, dan telah menghimbau masyarakat untuk menanam cabai tidak hanya di ladang, tetapi juga di pekarangan.

Penanaman cabai di lahan pekarangan sebagai penyangga, kalau produksi berlebih bisa dilakukan pengolahan seperti abon cabai, dan produksi cabai yang diusahakan petani bisa melakukan kerjasama dari berbagai pihak termasuk pihak swasta telah berhasil memberdayakan kelembagaan petani di kabupaten Garut , seperti kerjasama yang dilakukan Gapoktan Karang sari dengan PT.ABC Heinz. Pengembangan yang perlu diusahakan adalah perbaikan jenis cabai yang ditanam harus sesuai untuk cabai olahan, agar bisa diolah dengan baik, kalau mutunya baik konsumen akan beralih pada penggunaan cabai olahan, tidak hanya ketergantungan pada konsumsi cabai segar. 
Fluktuasi Harga Cabai Merah Keriting (Capsicum annum L) di Sentra Produksi dan Pasar Induk

(Tinjauan Harga Cabai Merah Keriting di Kecamatan Cikajang

dan Pasar Induk Kramat Jati Jakarta)

\section{DETY SUKMAWATI, LIES SULISTYOWATI, MAMAN H. KARMANA, E KUSNADI WIKARTA}

\section{PENUTUP}

Fluktuasi harga cabai merah kertiting di ke 2 tempat mengalami fluktuasi harga yang tinggi dari jenis sayuran lainnya. Cabai merah merupakan komoditas yang mengalami fluktuasi harga setiap waktu. Dalam kurun waktu 10 tahun perkembangan harga cabai merah di 2 tempat mengalami fluktuasi dengan rentang yang berbeda. Harga di pasar induk lebih berfluktuasi dari sentra produksi . Hal ini berdasar hasil analisis standar deviasi sentra produksi Cikajang $(15165,64)$ dan Pasar Induk Kramat Jati (18302,01). Ketidakstabilan harga tersebut dikarenakan di pasar mekanisme pasar tidak bekerja, distribusi antar pelaku pasar tidak adil hal ini menunjukkan bahwa pasar cabai merah tidak efisien atau tidak sehat. Pasar tidak sehat ditunjukkan dengan harga terlalu murah akan merugikan produsen, dan harga terlalu mahal merugikan konsumen, hal ini terjadi akibat perubahan penawaran dan permintaan yang menimbulkan fluktuasi harga sehingga fluktuasi harga secara ekonomi akan menyulitkan prediksi bisnis.

\section{DAFTAR PUSTAKA}

Agustian, Adang dan Setiajie, Iwan A. 2008. Analisis Perkembangan Harga dan Rantai Pemasaran Komoditas Cabai Merah di Provinsi Jawa Barat Seminar Nasional Dinamika Pembangunan Pertanian dan Perdesaan. Pusat Analisis Sosial Ekonomi dan kebijakan Pertanian Departemen Pertanian. Bogor.

Dinas Pertanian Tanaman Pangan provinsi Jawa Barat. 2013. Sentra Produksi Sayuran.Data Dinas Pertanian Tanaman Pangan Provinsi Jawa Barat.

Irawan, Bambang . 2007. Fluktuasi Harga , Transmisi Harga dan Marjin Pemasaran Sayuran dan Buah. Analisis kebijakan Pertanian vol 5 no 4 : 358-373. Pusat Analisis Sosial Ekonomi dan Kebijakan Pertanian, Bogor.

Ismet, Mohamad. 2009. Strategi dan Kebijakan Pemasaran Produk Agribinis dalam Bunga Rampai Agribinis Seri pemasaran. Departemen Agribisnis Fakultas Ekonomi dan Manajemen IPB. Bogor.

Musrhalis, Alex. 2007. Peramalan dan Faktorfaktor Penentu Fluktuasi Harga Cabai Merah di Enam Kota Besar Di Jawa -
Bali. Program Sarjana Ekstensi Manajemen Agribisnis Fa.kultas Pertanian Institut Pertanian Bogor.

Tambunan,T ulus.T.H. 2003. Perkembangan Sektor Pertanian di Indonesia: Beberapa Isu Penting .Ghalia Indonesia, Jakarta. 


\section{AIMBAR Agribisnis}

ISSN 2460-4321

Volume 1・Nomor 2・Januari 2016 